\title{
Thermodynamics of partitioning and solvation of ketoprofen in some organic solvent/buffer and liposome systems
}

\author{
Hernán Ricardo Lozano and Fleming Martínez*
}

Departamento de Farmacia, Universidad Nacional de Colombia

*Correspondence:

F. Martínez

Universidad Nacional de Colombia

Departamento de Farmacia

A.A. 14490

Bogotá, Colombia

E-mail: fmartinezr@unal.edu.co
The ketoprofen (KTP) partitioning thermodynamics was studied in different solvent/buffer systems such as cyclohexane $(\mathrm{CH} / W)$, octanol $(\mathrm{ROH} / W)$, isopropyl myristate (IPM/W), chloroform (CLF/ $W)$; as well as in dimyristoyl phosphatidylcholine (DMPC) and dipalmitoyl phosphatidylcholine (DPPC) liposome systems. In all cases, the rational partition coefficients $\left(K_{O / w}^{X}\right)$ were greater than unit; therefore standard transfer free energies were negative in sign indicating a high affinity of KTP for organic media. $K_{O / w}^{X}$ values were approximately eightyfive-fold higher in the $\mathrm{ROH} / \mathrm{W}$ system regarding the $\mathrm{CH} / \mathrm{W}$ system, thus indicating a high degree of hydrogen bonding contribution to partitioning. While in the case of IPM/W and $C L F / W$ systems, $K_{O / w}^{X}$ values were approximately only three or four-fold lower than those observed in $\mathrm{ROH} / W$. On the other hand, $K_{O / w}^{X}$ values were approximately seventy-five or one hundred fifty-fold higher in the liposomes compared to ROH/ $W$ system indicating a high degree of bilayers immobilization and/ or an electrostatic contribution to partitioning. In all cases, standard transfer enthalpies and entropies of KTP from water to organic media were positive in sign indicating some degree of participation of the hydrophobic hydration on the partitioning processes. Finally, by using the reported data for solvation of KTP in water, the associated thermodynamic functions for KTP solvation in all tested organic phases were also calculated.
Uniterms

- Ketoprofen

- Partition coefficient

- Organic solvents

- Liposomes

- Transfer thermodynamics

\section{INTRODUCTION}

Ketoprofen (KTP) is a non-steroidal antiinflammatory drug widely used in the treatment of several inflammatory and painful events (Hanson, 2000). Although KTP is widely used nowadays in therapeutics, the physicochemical information about transfer processes of this drug is very scarce. As useful information in medicinal chemistry, the thermodynamics of transfer of drug compounds can be studied by measuring the rational partition coefficient as a function of temperature. Such data can be used for the prediction of absorption, membrane permeability, and in vivo drug distribution (Betageri et al., 1996). 
Semi-polar solvents have been found to yield better correlations with partitioning of solutes obtained in model membranes compared to non-polar solvents such as cyclohexane $(\mathrm{CH})$, which interacts only by non-specific forces (London interactions). In particular, octanol (ROH) has been found to be a useful solvent as the reference for extrathermodynamic studies in a variety of systems (Leo et al., 1971; Diamond, Katz, 1974; Sangster, 1997), Isopropyl myristate (IPM) has also been used. This solvent acts as a hydrogen acceptor as well, and it has been used especially for determining hydrophobic constants since it simulates most closely the corneum stratum/water partition (Barker, Hadgraft, 1981; Dal Pozzo et al., 1991). IPM is best related to skin/transdermal absorption because of its polar and non-polar balance simulates the complex nature (polar/non-polar matrix) of the skin (Jaiswal et al., 1999). On the other hand, chloroform (CHL) has also been used in this kind of studies since it acts mainly as a hydrogen donor for establishing hydrogen bonds with solutes (Baena et al., 2004a).

However, the octanol/water system has proven to be a poor model system for several drug transport processes as well as for correlating pharmacokinetic parameters. On the other hand, when analyzing the behavior of several drugs, the liposome systems have shown to discriminate branched solutes regarding bulk systems such as oil/water. This has been found especially in the case of some phenols (Rogers, Davis, 1980; Anderson et al., 1983), phenotiazines (Ahmed et al., 1981, 1985), beta-blockers (Betageri, Rogers, 1987), and non-steroidal antiinflammatory drugs (Betageri et al., 1996). In addition, dipyridamole partitioning was higher in liposomes than in octanol (Betageri, Dipali, 1993), as well as for mefloquine, quinine, and other antimalarial drugs (Go et al., 1995, 1997), also for some sulfonamides (Martínez, Gómez, 2002), and benzocaine (Avila, Martínez, 2003). For these reasons, different liposome types have been used combined to organic solvents for partitioning experiments in order to develop quantitative structure-activity relationships (QSAR studies).

As a contribution to generation and systematization of physicochemical information about anti-inflammatory drugs transfer properties, the main goal of this study was to compare the partitioning and solvation behavior of KTP in different organic medium/buffer systems, namely: cyclohexane $(\mathrm{CH} / \mathrm{W})$, octanol $(\mathrm{ROH} / \mathrm{W})$, isopropyl myristate (IPM/W), chloroform (CLF/W), and dimyristoyl phosphatidylcholine (DMPC/W) as well as dipalmitoyl phosphatidylcholine (DPPC/W) liposome systems, by employing a thermodynamic approach based on the rational partitioning variation respect to temperature. From the obtained values of the corresponding thermodynamic transfer functions, an interpretation based on solute-solvent interactions was developed. Therefore, the present study is a continuation of a previously presented (Lozano, Martínez, 2006).

\section{THEORETICAL}

The partition coefficient $\left(K_{o / w}^{m}\right)$ expressed in molality, for any solute between organic and aqueous phases is calculated by means of:

$$
K_{o / w}^{m}=W_{w} \frac{C_{1}-C_{2}}{C_{2} W_{o}}
$$

where, $W_{w}$ and $W_{o}$ are the masses (usually in g) of aqueous and organic phases, respectively, and $C_{1}$ and $C_{2}$ are the aqueous concentrations of solute (usually in $\mathrm{mg} \mathrm{mL}^{-1}$ ) before and after the transfer of the solute from the aqueous phase to the organic medium, respectively (Avila, Martínez, 2003). The rational partition coefficients $\left(K_{o / w}^{X}\right.$, in mole fraction) are calculated from $K_{o / w}^{m}$ values as:

$$
K_{o / w}^{X}=K_{o / w}^{m}\left(M_{o} / M_{w}\right)
$$

where, $M_{o}$ and $M_{w}$ are the molar masses of the organic and aqueous phases, respectively (Diamond, Katz, 1974).

The standard change for Gibbs free energy of transfer of a solute from an aqueous phase to an organic medium is calculated as follows:

$$
\Delta G_{w \rightarrow o}^{0 X}=-R T \ln K_{o / w}^{X}
$$

Otherwise, the enthalpy change for the transfer may be obtained directly by thermometric titration microcalorimetry or in the case of liquid/liquid systems, indirectly as the difference of the respective heats of solution in each one of the phases, which may be obtained by solution calorimetry (Baena et al., 2004b). As it was mentioned previously, a method widely used in the physicochemical study of pharmaceutical compounds (such as drugs) is by means of the analysis of the temperature-dependence for partitioning by using the van't Hoff method. This procedure permits obtain the standard enthalpy change $\left(\Delta H_{w \rightarrow 0}^{0 X}\right)$ from:

$$
\left(\frac{\partial \ln K_{o / w}^{X}}{\partial(1 / T)}\right)_{P}=-\frac{\Delta H_{w \rightarrow o}^{0 X}}{R}
$$

Therefore, $\Delta H_{w \rightarrow o}^{0 X}$ is determined from the slope of a pondered linear plot of $\ln K_{o / w}^{X}$ as a function of $1 / T$. The standard entropy change of transfer is obtained by means of: 


$$
\Delta S_{w \rightarrow o}^{0 X}=\frac{\Delta H_{w \rightarrow o}^{0 X}-\Delta G_{w \rightarrow o}^{0 X}}{T}
$$

The thermodynamic functions $\Delta H_{w \rightarrow 0}^{0 X}$ and $\Delta S_{w \rightarrow 0}^{0 X}$ represent the standard changes in enthalpy and entropy, respectively, when one mole of drug is transferred from the aqueous medium to the organic system at infinite dilution expressed in the mole fraction scale (Betageri et al., 1996; Martínez, Gómez, 2002).

\section{MATERIAL AND METHODS}

\section{Chemicals}

In this investigation the following chemicals were used: USP ketoprofen (US Pharmacopeia, 2004); extra pure grade octanol (Merck, Germany); isopropyl myristate for synthesis (Merck, Germany); cyclohexane A.R. (Merck, Germany); chloroform A.R. (Mallinckrodt, USA); DMPC (ref P-7331), and DPPC (ref P-5911) (Sigma Chemical Co., USA); potassium chloride A.R. (Merck, Germany); sodium mono and dihydrogen phosphates A.R. (Merck, Germany); distilled water (conductivity $<2 \mu \mathrm{S}$ ).

\section{Organic Solvent/Buffer Partitioning}

Both, the aqueous and organic solvents were mutually saturated before performing the experiments. Solutions of KTP at known concentrations were prepared in aqueous buffers adjusted to $\mathrm{pH} 7.4$ at ionic strength of $0.15 \mathrm{~mol} \mathrm{~L}^{-1}$ (physiological values (Cevc, 1993)). Then, in glass flasks specific volumes of organic solvents were added to specific volumes of the aqueous KTP solutions. The employed volumes were as follows: for $\mathrm{ROH} / \mathrm{W}, 10 \mathrm{~mL}$ of $\mathrm{ROH}$ and $20 \mathrm{~mL}$ of $\left(150 \mu \mathrm{g} \mathrm{mL}^{-1}\right)$ $\mathrm{KTP}$ aqueous solution; for $\mathrm{CH} / \mathrm{W}, 20 \mathrm{~mL}$ of $\mathrm{CH}$ and 10 $\mathrm{mL}$ of $\left(125 \mu \mathrm{g} \mathrm{mL}^{-1}\right) \mathrm{KTP}$ aqueous solution; for IPM/W, $20 \mathrm{~mL}$ of IPM and $10 \mathrm{~mL}$ of $\left(125 \mu \mathrm{g} \mathrm{mL}^{-1}\right) \mathrm{KTP}$ drug aqueous solution; for $\mathrm{CHL} / \mathrm{W}, 15 \mathrm{~mL}$ of CHL and $15 \mathrm{~mL}$ of $\left(150 \mu \mathrm{g} \mathrm{mL}^{-1}\right) \mathrm{KTP}$ aqueous solution. All aliquots were weighted in a digital analytical balance (Mettler AE 160 , Germany) whose sensitivity was $\pm 0.1 \mathrm{mg}$. Mixtures were then stirred on a mechanical shaker (Wrist Action Burrel model 75, USA) for one hour. Samples were placed on water baths (Magni Whirl Blue M. Electric Company, USA) at 20.0, 25.0, 30.0, 35.0, 40.0 , and $45.0^{\circ} \mathrm{C}\left( \pm 0.1{ }^{\circ} \mathrm{C}\right)$ at least for 48 hours with sporadic stirring in order to achieve the partitioning equilibrium, as it was made studying other compounds (Martínez, Gómez, 2002). After this time-period, the aqueous phase was removed followed by determining the drug concentration by means of UV absorbance measurement and interpolation on a previously constructed calibration curve for KTP in a buffer $\mathrm{pH} 7.4$ (Unicam UV2-100 spectrophotometer, USA). The apparent molal partition coefficients $\left(K_{O / w}^{m / a p p}\right)$ were calculated by mass balance according to Eq. (1) and converted to real molal partition coefficients $\left(K_{O / w}^{m}\right)$ by using the following equation:

$$
K_{o / w}^{m}=K_{o / w}^{m / a p p}\left(1+10^{p H-p K a}\right)
$$

in which, the parenthesis term on the right side is equal to 1231.27 since the $\mathrm{pH}$ is 7.4 and the $\mathrm{p} K$ of KTP corrected to an ionic strength of $0.15 \mathrm{~mol} \mathrm{~L}^{-1}$ is 4.31 (Table I). From $K_{O / w}^{m}$ values, the rational partition coefficients $\left(K_{O / w}^{X}\right)$ were calculated from the Eq. (2) employing the following molar masses: $99.48 \mathrm{~g} \mathrm{~mol}^{-1}$ for water-saturated $\mathrm{ROH}$, $263.72 \mathrm{~g} \mathrm{~mol}^{-1}$ for water-saturated IPM, $113.90 \mathrm{~g} \mathrm{~mol}^{-1}$ for water saturated CLF, $84.16 \mathrm{~g} \mathrm{~mol}^{-1}$ for water-saturated $\mathrm{CH}, 18.16 \mathrm{~g} \mathrm{~mol}^{-1}$ for (ROH, IPM or $\mathrm{CH}$ ) organic solvents saturated buffer, and $18.62 \mathrm{~g} \mathrm{~mol}^{-1}$ for CHL-saturated buffer (Dallos, Liszi, 1995; Baena et al., 2005; Mora et al., 2005).

\section{Liposome/Buffer Partitioning}

Liposomes were prepared by a modified Bangham method (1993) as it was made studying other compounds (Betageri et al., 1996; Martínez, Gómez, 2002). Thin films of $40 \mathrm{mg}$ of DMPC or DPPC were formed on the walls of $50 \mathrm{~mL}$ round-bottomed flasks after rotary evaporation (Buchler Instr.) of $5 \mathrm{~mL}$ aliquots of chloroform solutions $\left(8 \mathrm{mg} \mathrm{mL}^{-1}\right)$. Then all flasks were placed in an oven at $40^{\circ} \mathrm{C}$ for $2 \mathrm{~h}$. Thereafter the films were dispersed in $4 \mathrm{~mL}$ of $\mathrm{KTP}$ aqueous solution $\left(250 \mu \mathrm{g} \mathrm{mL}^{-1}, \mathrm{pH} 7.4\right.$ and $\left.\mu 0.15 \mathrm{~mol} \mathrm{~L}^{-1}\right)$, then were heated at $30{ }^{\circ} \mathrm{C}$ (for DMPC) or $45^{\circ} \mathrm{C}$ (for DPPC), and vortex-mixed (Mistral ${ }^{\circledR}$ Mixer, Model 1192, Lab-Line Instr.) until the whole film was removed from the flask walls. This resulted in formation of multi-lamellar vesicles (MLVs). The drug distribution was determined in 48 hours temperature-equilibrated MLVs in $1.3 \mathrm{~mL}$ samples, followed by centrifugation ( $25000 \mathrm{~g}$ for $60 \mathrm{~min}$ ) at the specified temperature, from UV analysis and mass balance calculations ranging from $20.0^{\circ} \mathrm{C}$ to $45.0^{\circ} \mathrm{C}$. The apparent and true partition coefficients were calculated by using the same equations as in organic solvent/buffer partitioning. The molar masses for lecithins are $677.90 \mathrm{~g} \mathrm{~mol}^{-1}$ for DMPC and $734.05 \mathrm{~g} \mathrm{~mol}^{-1}$ for DPPC. All partitioning experiments were repeated at least three times and the produced data were averaged. 


\section{RESULTS AND DISCUSSION}

\section{KTP physical and chemical properties}

The molecular structure and some physicochemical properties of KTP are summarized in table I. The $\mathrm{p} K_{\mathrm{a}}$ value was corrected to ionic strength $(\mu)$ of $0.15 \mathrm{~mol} \mathrm{~L}^{-1}$ ( similar to that of the gastrointestinal tract and blood (Cevc, 1993)) by the extended Debye-Hückel equation (Martin et al., 1993). The partitioning was determined at $\mathrm{pH} 7.4$ (resembling the blood physiological value). Such $\mathrm{pH}$ value was regulated with phosphate buffer having $\beta$ capacity of 0.01 calculated by the Koppel-Spiro-Van Slyke equation (Martin et al., 1993) using $\mathrm{p} K_{\mathrm{a}}$ values corrected to $\mu$ $0.15 \mathrm{~mol} \mathrm{~L}^{-1}$. At this $\mathrm{pH}$ the KTP has a lower apparent partition coefficient value since the dissociated compound form predominates thus having more affinity for water. This fact conduces to use Eq. (6) to obtain the true values in order to follow the Nernst law, which implies no association or dissociation of the drug, in organic or aqueous phases (Sangster, 1997).

\section{Partition coefficients of KTP}

Temperature-dependence of the rational partition coefficients for the KTP in all tested partitioning systems is summarized in Table II. In all cases $K_{o / w}^{X}$ values are greater than unit and increased with rising temperature. Partitioning diminishes at $25.0^{\circ} \mathrm{C}$ in the following order: $\mathrm{DMPC} / \mathrm{W}>\mathrm{DPPC} / \mathrm{W}>\mathrm{ROH} / \mathrm{W}>\mathrm{CLF} / \mathrm{W}>\mathrm{IPM} / \mathrm{W}>$ $\mathrm{CH} / \mathrm{W}$, which is similar to data found for other drugs (Martínez, Gómez, 2002; Ávila, Martínez, 2003). Found data are in agreement that this drug displays a semi-polar and lipophilic behavior.

Betageri et al. (1996) has previously reported data regarding this drug partitioning in the $\mathrm{ROH} / \mathrm{W}$ and $\mathrm{DMPC} /$ W systems at $\mathrm{pH} 7.0$ expressed as a molal scale. Nevertheless, the results presented in table II are not in

TABLE I - Physical and chemical properties of KTP

Molecular structure
(a)

TABLE II - Rational partition coefficient of KTP in different partitioning systems as a function of temperature $\left( \pm 0.05^{\circ} \mathrm{C}\right)$. (Values in parenthesis are standard deviations)

\begin{tabular}{lcccccc}
\hline System & \multicolumn{7}{c}{$\boldsymbol{K}_{\boldsymbol{o} / \boldsymbol{w}}^{\boldsymbol{X}}$} \\
\cline { 2 - 7 } & $\mathbf{2 0 . 0 0}{ }^{\circ} \mathbf{C}$ & $\mathbf{2 5 . 0 0}{ }^{\circ} \mathbf{C}$ & $\mathbf{3 0 . 0 0}^{\circ} \mathbf{C}$ & $\mathbf{3 5 . 0 0}^{\circ} \mathbf{C}$ & $\mathbf{4 0 . 0 0}^{\circ} \mathbf{C}$ & $\mathbf{4 5 . 0 0}^{\circ} \mathbf{C}$ \\
\hline $\mathrm{CH} / \mathrm{W}$ & 61 & 82 & 104 & 142 & 175 & 297 \\
& $(5)$ & $(5)$ & $(8)$ & $(8)$ & $(8)$ & $(23)$ \\
$\mathrm{ROH} / \mathrm{W}$ & 6850 & 7069 & 7321 & 7690 & 8250 & 9510 \\
& $(50)$ & $(20)$ & $(27)$ & $(70)$ & $(50)$ & $(70)$ \\
$\mathrm{IPM} / \mathrm{W}$ & 1670 & 1760 & 1860 & 2130 & 2350 & 2700 \\
& $(50)$ & $(70)$ & $(50)$ & $(70)$ & $(70)$ & $(110)$ \\
$\mathrm{CLF} / \mathrm{W}$ & 2100 & 2210 & 2320 & 2500 & 2920 & 3170 \\
& $(60)$ & $(80)$ & $(60)$ & $(110)$ & $(50)$ & $(60)$ \\
$\mathrm{DMPC} / \mathrm{W}$ & 289000 & 1041000 & 1402000 & 1841000 & 2469000 & 3400000 \\
& $(17000)$ & $(42000)$ & $(40000)$ & $(22000)$ & $(54000)$ & $(110000)$ \\
$\mathrm{DPPC} / \mathrm{W}$ & 382000 & 541000 & 751000 & 1088000 & 1695000 & 5872000 \\
& $(22000)$ & $(19000)$ & $(24000)$ & $(22000)$ & $(13000)$ & $(95000)$ \\
\hline
\end{tabular}


agreement with those presented in literature when they were converted to mole fraction. Particularly, for the DMPC/W system according to Betageri et al. (1996), it was found diminished $K_{o / w}^{X}$ values when increasing the working temperature, which is on the contrary with data presented in the present study. On the other hand, accordingly to graphical results presented in the same reference (Betageri et al., 1996), apparently the KTP molal partition is similar in both $\mathrm{ROH} / \mathrm{W}$ and DMPC/W systems, which is not in agreement to Table II data even if partition coefficients are converted to molality (Lozano, Martínez, 2006).

According to Table II, the partitioning in DMPC is almost one hundred fifty-fold greater than its obtained value in $\mathrm{ROH} / \mathrm{W}$ at $25.0^{\circ} \mathrm{C}$. When comparing the results obtained for all organic solvents, it can be deduced a higher preference of KTP for octanol, respect to the other tested solvents, in particular regarding cyclohexane. As has been previously described in literature (Sangster, 1997; Mora et al., 2005), ROH has a microheterogeneus structure on water saturation. For this reason, $\mathrm{ROH}$ interacts with KTP by hydrogen bonding thorough carbonyl and carboxyl groups present in this drug, in addition to weak interactions, such as London dispersion forces, which conduce to structural immobilization of drug molecules near to the alkyl moieties of octanol.

As it was already discussed, the phospholipidic vesicles have been investigated as model for studying drug distribution in membranes, since liposomes resemble the ordered structures present in biological membranes. As it is shown in Table II, partitioning is higher in these systems compared to $\mathrm{ROH} / \mathrm{W}$. This fact demonstrates a high contribution to partitioning by the drug immobilization inside the bilayers, in addition to electrostatic interactions with the polar head of phospholipids as has been described in the literature (Ahmed et al., 1981, 1985; Betageri, Rogers, 1987; Betageri, Dipali, 1993; Abe et al., 1995). In addition, the vesicles can immobilize the drug in the space available within the bilayers increasing the KTP solubilization. On the other hand, some surface phenomena due to the possible amphiphilic nature of KTP would be also considered because the interfaces' nature would be modified. This consideration has been done recently by studying the behavior of ibuprofen in micellar solutions of ionic and non-ionic surfactants (Stephenson et al., 2006).

Comparing the results obtained in the liposome system, the partitioning is higher in DMPC/W with respect to $\mathrm{DPPC} / \mathrm{W}$ ranging from 25.0 to $40.0^{\circ} \mathrm{C}$. Such a behavior could be explained in terms of the respective aggregation states of liposomes. That is, in this range the DMPC liposomes are in a fluid state (liquid crystal) while DPPCliposomes are in a rigid state (gel) since the transition gelliquid crystal temperature $\left(T_{C}\right)$ for these compounds are $23.6( \pm 1.5){ }^{\circ} \mathrm{C}$ and $41.3( \pm 1.8)^{\circ} \mathrm{C}$, respectively (Koynova, Caffrey, 1998). Therefore, liposomes flexibility and permeability is greater in a fluid state than in a rigid state, i.e. at temperatures higher than $T_{C}$.

On the other hand, when partitioning is compared for liposomes present in the same state, partitioning is higher for DPPC/W respect to DMPC/W, i.e. at $20.0^{\circ} \mathrm{C}$ both liposome systems are in a gel state (rigid) while at $45.0^{\circ} \mathrm{C}$ both liposome systems are in liquid crystal state (flexible). In particular, this result could be considered as an additional demonstration about the lipophilic nature of this drug since DPPC has two additional methylene groups in each hydrocarbon moiety with respect to DMPC. Nevertheless, certainly KTP is not a hydrophobic drug because $\mathrm{CH} / \mathrm{W}$ partitioning is relatively low when compared to that obtained in the other organic solvents. In this point, it is very important to remark that it will be very important to analyze the surface behavior of this drug in other organic systems such as micelles, in order to evaluate if KTP is amphiphilic in nature, as it was demonstrated for ibuprofen by Stephenson et al. (2006).

\section{Seiler and other analogue parameters}

Seiler (1974) proposed an equation analogue to Eq. (7) in order to compare partition coefficients of a drug in the $\mathrm{ROH} / \mathrm{W}$ and $\mathrm{CH} / \mathrm{W}$ systems, with the basic purpose of obtaining information related to contribution of hydrogen bonding for partitioning of solutes. In a more complete treatment, other considerations such as molecular geometry and steric effects of solutes and solvents should be considered for such aim. However in a first approach, Eq. (7) is a good attempt for identifying the main solute-solvent interactions affecting the solute transfer:

$$
\Delta \log K_{R O H / W}=\log K_{\text {ROH /W }}^{X}-\log K_{C H / W}^{X}
$$

The above equation may also be written as a quotient relationship in the form $\Delta \log K_{R O H / W}^{X}=\log \left(K_{R O H / W}^{X} / K_{C H}^{X}\right)$ showing the hydrogen bonding nature of the interactions between the drug and octanol with respect to cyclohexane. If $\Delta \log K_{R O H / W}^{X}$ is greater than 0 , then this result indicates some contribution of hydrogen bonding to the partitioning of drugs. Table III presents the values of parameter of Seiler and other analogous parameters for KTP at $25.0^{\circ} \mathrm{C}$, calculated from the different rational partition coefficients showed in table II. 
TABLE III - Seiler and other analogue parameters of KTP at $25.00 \pm 0.05{ }^{\circ} \mathrm{C}$

\begin{tabular}{lccccc}
\hline Parameter & System 1 & System 2 & $\log \boldsymbol{K}_{\boldsymbol{o} / \boldsymbol{w}}^{X}(\boldsymbol{S y s t} \mathbf{1})$ & $\log \boldsymbol{K}_{\boldsymbol{o} / \boldsymbol{w}}^{X}(\boldsymbol{S y s t 2 )}$ & $\Delta \log \boldsymbol{K}_{\boldsymbol{o} / \boldsymbol{w}}^{X}(\boldsymbol{a})$ \\
\hline$\Delta \log K_{R O H / W}^{X}$ & $\mathrm{ROH} / \mathrm{W}$ & $\mathrm{CH} / \mathrm{W}$ & 3.849 & 1.915 & 1.935 \\
$\Delta \log K_{I P M / W}^{X}$ & $\mathrm{IPM} / \mathrm{W}$ & $\mathrm{CH} / \mathrm{W}$ & 3.245 & 1.915 & 1.331 \\
$\Delta \log K_{C L F / W}^{X}$ & $\mathrm{CLF} / \mathrm{W}$ & $\mathrm{CH} / \mathrm{W}$ & 3.344 & 1.915 & 1.429 \\
$\Delta \log K_{R O H / W}^{X \alpha}$ & $\mathrm{ROH} / \mathrm{W}$ & $\mathrm{IPM} / \mathrm{W}$ & 3.849 & 3.245 & 0.604 \\
$\Delta \log K_{R O H / W}^{X \beta}$ & $\mathrm{ROH} / \mathrm{W}$ & $\mathrm{CLF} / \mathrm{W}$ & 3.849 & 3.344 & 0.505 \\
$\Delta \log K_{D M P C / W}^{X}$ & $\mathrm{DMPC} / \mathrm{W}$ & $\mathrm{ROH} / \mathrm{W}$ & 6.017 & 3.849 & 2.168 \\
$\Delta \log K_{D P P C / W}^{X}$ & $\mathrm{DPPC} / \mathrm{W}$ & $\mathrm{ROH} / \mathrm{W}$ & 5.733 & 3.849 & 1.884 \\
\hline
\end{tabular}

(a) $\Delta \log K_{o / w}^{X}=\log K_{o / w}^{X}($ Syst 1$)-\log K_{o / w}^{X}($ Syst2)

$\mathrm{CH}$ is an aprotic solvent unable to form hydrogen bonds as donor or acceptor, and therefore acts only through non-specific interactions (London forces). However hydroxyl group of $\mathrm{ROH}$ can be an acceptor and/or a donor of protons, and moreover, as was already expressed, its alkyl moieties allow the structural immobilization of solutes due to the tetrahedral microstructure adopted in saturation by this solvent in contrast to the $\mathrm{CH}$ behavior (Sangster, 1997; Mora et al., 2005). $\Delta \log K_{R O H / W}^{X}$ includes contributions by hydrogen bonding and by structural immobilization to the partitioning (in this analysis is considered that the non-specific interactions are similar for all organic solvents and drugs).

$\Delta \log K_{I P M / W}^{X}$ allows to estimate the contribution of the solvent as hydrogen bonding acceptor in IPM/W rational partitioning. By comparison of Seiler parameter $\left(\Delta \log K_{R O H / W}^{X}\right)$ with $\Delta \log K_{I P M / W}^{X}$ it shows that the octanol, besides of contributing to the drug partitioning as acceptor of hydrogen, may also contribute as hydrogen donor, therefore $\Delta \log K_{I P M / W}^{X}$ value is smaller than the Seiler parameter. A third parameter, namely: $\Delta \log K_{R O H / W}^{X \alpha}$ was calculated comparing the $\mathrm{ROH} / \mathrm{W}$ and IPM/W partition coefficients in order to establish the contribution of the organic solvent as hydrogen donor to the partitioning. As it was already said, CHL acts mainly as hydrogen donor and therefore, other two parameters were calculated in order to analyze the contribution of this kind of interaction on the partitioning of KTP. $\Delta \log K_{C L F / W}^{X}$ permits to observe the possible contribution of CLF as hydrogen donor, while $\Delta \log K_{R O H / W}^{X \beta}($ obtained from $\mathrm{ROH} / \mathrm{W}$ and CLF/W) on the other side permits to evaluate the behavior of $\mathrm{ROH}$ as hydrogen acceptor.

Generally, the results show greater $\Delta \log K_{o / w}^{X}$ values when the drug acts as an hydrogen acceptor $\left(\Delta \log K_{C L F / W}^{X}\right.$ and $\left.\Delta \log K_{R O H / W}^{X \alpha}\right)$ respect to those obtained when the drug acts as hydrogen donor $\left(\Delta \log K_{I P M / W}^{X}\right.$ and $\left.\Delta \log K_{R O H / W}^{X \beta}\right)$. The acid hydrogen present in this drug is the one present in its carboxylic group. On the other hand, the basic groups (hydrogen acceptor) in KTP are the carbonyl group present between two aromatic rings and the carbonyl moiety in the carboxyl group. At this point, it is convenient to remind that in the previously made analyses we consider only the effect of hydrogen bonding without consider other kind of interactions or geometric parameters, such as differences in molecular sizes.

More recently, Eq. (8) has been exposed in order to obtain information about the higher distribution of drugs inside liposome bilayers compared to that obtained in octanol (Avila, Martínez, 2003).

$$
\Delta \log K_{D M P C / W}^{X}=\log K_{D M P C / W}^{X}-\log K_{R O H / W}^{X}
$$

The $\Delta \log K_{D M P C / W}^{X}$ parameter allows estimating the contribution to partitioning by structural immobilization and by solute-lipid electrostatic effects depending on the phospholipid employed for preparing of liposomes; that is, depending on the $\mathrm{pH}$, the alkyl moiety length, and the possible presence of ionic charges in the phospholipids' polar heads, thus the results may be variable (Ahmed et al., 1981, 1985; Betageri, Rogers, 1987; Betageri, Dipali, 1993). Table IV shows that the effect due to immobilization is higher in DMPC liposomes than in DPPC liposomes. This behavior can be explained in terms of the liposome aggregation state according to the temperature. As was already exposed, in the studied range the DMPC liposomes are in a liquid crystal state (fluid), whereas the DPPC liposomes are in a gel state (rigid).

\section{KTP Partitioning Thermodynamics}

Van't Hoff plots for CH/W, ROH/W, IMP/W and $\mathrm{CLF} / \mathrm{W}$ partitioning of KTP are shown in figures 1, 2 and 3 , respectively. For $\mathrm{CH} / \mathrm{W}$ system (Figure 1) a lineal regression model was developed without consider the obtained value at $45.0^{\circ} \mathrm{C}$, because deviates from the tendency followed by the other five points. The obtained 
determination coefficient was 0.979 . For the $\mathrm{ROH} / \mathrm{W}$ system (Figure 2) a parabolic regression model was developed without consider the value at $45.0^{\circ} \mathrm{C}$, because it also deviates from the tendency followed by the other stated points. In this case, the determination coefficient was 0.993. For IPM/W and CLF/W systems (Figure 3), parabolic regression models were developed considering all the obtained data. Determination coefficients were 0.968 and 0.961 , respectively.

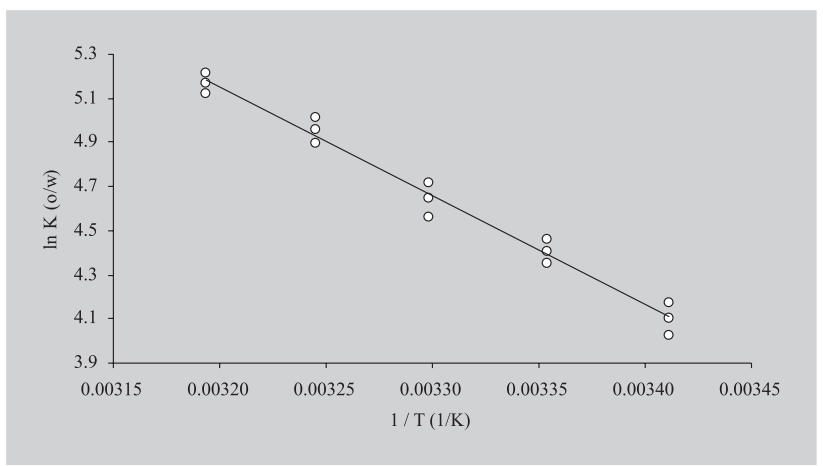

FIGURE 1 - Van't Hoff plot for the rational partitioning of $\mathrm{KTP}$ in the $\mathrm{CH} / \mathrm{W}$ system.

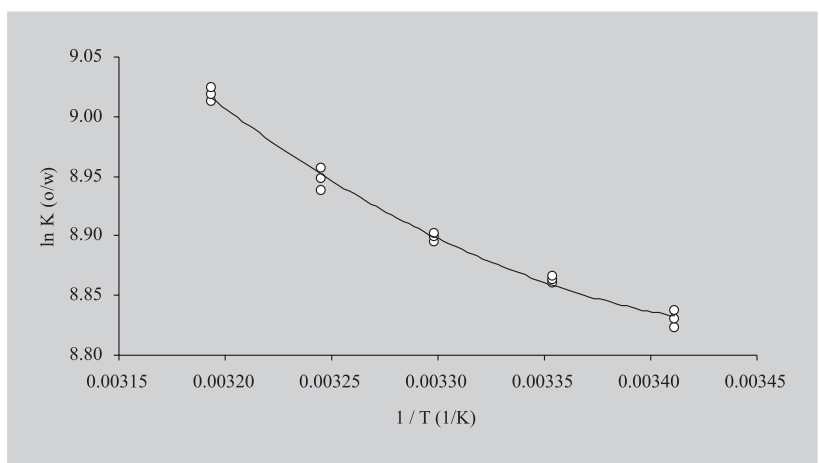

FIGURE 2 - Van't Hoff plot for the rational partitioning of $\mathrm{KTP}$ in the ROH/W system.

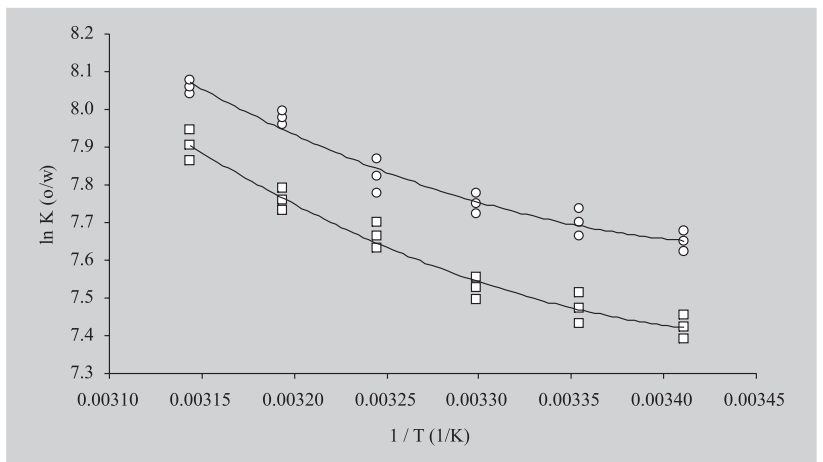

FIGURE 3 - Van't Hoff plot for the rational partitioning of KTP in the CLF/W (circles) and IPM/W (squares) systems.
Figure 4 shows the van't Hoff plot for KTP partitioning in DMPC and DPPC liposomes. In both cases the results were adjusted to lineal regression models considering the temperature intervals for which the liposomes are in the same aggregation state. Determination coefficients were 0.995 and 0.991 , for DMPC and DPPC respectively. As it was already explained, transition temperatures for DMPC and DPPC liposomes are 23.6 and $41.3{ }^{\circ} \mathrm{C}$ respectively (Koynova, Caffrey, 1998). Therefore, temperature intervals considered were from 25.0 to $45.0{ }^{\circ} \mathrm{C}$ for DMPC (fluid state) and from 20.0 to $40.0^{\circ} \mathrm{C}$ for DPPC (rigid state).

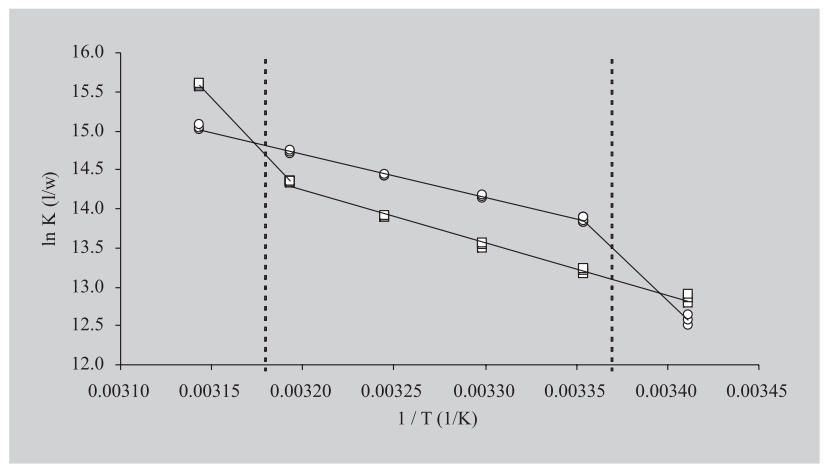

FIGURE 4 - Van't Hoff plot for the rational partitioning of $\mathrm{KTP}$ in the DMPC (circles) and DPPC (squares) liposome systems. Vertical discontinued lines are the phase transition temperatures for liposomes: $23.6^{\circ} \mathrm{C}$ and $41.3{ }^{\circ} \mathrm{C}$, for DMPC and DPPC, respectively.

From the estimated slopes in the $\mathrm{CH} / \mathrm{W}, \mathrm{DMPC} / \mathrm{W}$ and DPPC/W systems, the respective standard enthalpic changes for transfer were calculated by using Eq. (4) using methods of error propagation (Bevington, 1969). In the case of ROH/W, IPM/W and CLF/W systems, in which parabolic regressions were obtained, the first derivatives were taken for these models and resolved at $25.0^{\circ} \mathrm{C}$. Then, transfer enthalpies $\left(\Delta H_{w \rightarrow 0}^{0 X}\right)$ were calculated as the product of slopes multiplied by $-R$ (that is, $-8.314 \mathrm{~J} \mathrm{~mol}^{-1} \mathrm{~K}^{-1}$ ). The obtained values for this thermodynamic function are summarized in table IV, in addition to standard Gibbs free energy for transfer $\left(\Delta G_{w \rightarrow 0}^{0 X}\right)$ of KTP from water to different organic systems (expressed in mole fraction at $25.0^{\circ} \mathrm{C}$ ). The $\Delta G_{w \rightarrow o}^{0 X}$ values were calculated by means of Eq. (3) based on partitioning data of Table II using methods of errors propagation (Bevington, 1969). In all cases, $\Delta G_{w \rightarrow 0}^{0 X}$ was negative in sign indicating the preference of this drug for organic media.

On the other hand, from $\Delta G_{w \rightarrow o}^{0 X}$ and $\Delta H_{w \rightarrow o}^{0 X}$ values, the respective standard entropic changes of transfer $\left(\Delta S_{w \rightarrow 0}^{0 X}\right)$ in mole fraction were calculated from Eq. (5). 
TABLE IV - Standard Gibbs free energy $\left(\Delta G_{w \rightarrow 0}^{0 X}\right)$, enthalpy $\left(\Delta H_{w \rightarrow 0}^{0 X}\right)$, and entropy $\left(\Delta S_{w \rightarrow 0}^{0 X}\right)$ of KTP transfer from water to different organic systems. Relative contributions of enthalpy $\left(\zeta_{H}\right)$ and entropy $\left(\zeta_{T S}\right)$ toward transfer processes at 25.00 $\pm 0.05^{\circ} \mathrm{C}$. (Values in parenthesis are standard deviations)

\begin{tabular}{|c|c|c|c|c|c|c|}
\hline System & $\begin{array}{l}\Delta G_{w \rightarrow o}^{0 X} \\
\mathbf{k J ~ m o l}^{-1}\end{array}$ & $\begin{array}{l}\Delta H_{w \rightarrow 0}^{0 X} \\
\mathrm{~kJ} \mathrm{~mol}^{-1}\end{array}$ & $\begin{array}{c}\Delta S_{w \rightarrow 0}^{0 X} / \\
\mathbf{J ~ m o l}^{-1} \mathbf{K}^{-1}\end{array}$ & $\begin{array}{c}T \Delta S_{w \rightarrow o^{\prime X}}^{0 X} \\
\mathrm{~kJ} \mathrm{~mol}^{-1}\end{array}$ & $\zeta_{H}$ & $\zeta_{T S}$ \\
\hline $\mathrm{CH} / \mathrm{W}$ & $\begin{array}{c}-10.93 \\
(0.14)\end{array}$ & $\begin{array}{l}40.9 \\
(1.7)\end{array}$ & $\begin{array}{l}174 \\
(7)\end{array}$ & 51.8 & 44.1 & 55.9 \\
\hline $\mathrm{ROH} / \mathrm{W}$ & $\begin{array}{c}-21.97 \\
(0.01)\end{array}$ & $\begin{array}{c}4.94 \\
(0.25)\end{array}$ & $\begin{array}{l}90 \\
(5)\end{array}$ & 26.9 & 15.5 & 84.5 \\
\hline IPM/W & $\begin{array}{c}-18.52 \\
(0.10)\end{array}$ & $\begin{array}{c}9.3 \\
(0.6)\end{array}$ & $\begin{array}{l}34.8 \\
(2.4)\end{array}$ & 10.4 & 47.2 & 52.8 \\
\hline CLF/W & $\begin{array}{c}-19.09 \\
(0.09)\end{array}$ & $\begin{array}{c}7.8 \\
(0.6)\end{array}$ & $\begin{array}{l}29.2 \\
(2.1)\end{array}$ & 8.7 & 47.2 & 52.8 \\
\hline DMPC/W & $\begin{array}{c}-34.35 \\
(0.10)\end{array}$ & $\begin{array}{l}46.3 \\
(0.9)\end{array}$ & $\begin{array}{c}270 \\
(5)\end{array}$ & 80.6 & 36.5 & 63.5 \\
\hline DPPC/W & $\begin{array}{r}-32.72 \\
(0.09)\end{array}$ & $\begin{array}{l}56.2 \\
(1.5)\end{array}$ & $\begin{array}{c}298 \\
(8)\end{array}$ & 88.9 & 38.7 & 61.3 \\
\hline
\end{tabular}

These values are also presented in Table IV. The $\Delta H_{w \rightarrow 0}^{0 X}$ values presented in Table IV are almost the same obtained for $\mathrm{CH} / \mathrm{W}, \mathrm{ROH} / \mathrm{W}, \mathrm{DMPC} / \mathrm{W}$ and $\mathrm{DPPC} / \mathrm{W}$ partitioning expressed in molality (Lozano, Martínez, 2006) because this property is not dependent on the concentration scale used (Katz, Diamond, 1974). On the other hand, $\Delta G_{w \rightarrow 0}^{0 X}$ and $\Delta S_{w \rightarrow o}^{0 X}$ values are different with respect to those obtained using molality because they imply the concentration scale used in calculating partition coefficients. Moreover, the considered reference states are different in both cases, that is, ideal solutions of drug having unit mole fraction in each phase (solute pure) in the former case, and ideal solutions of drug having $1.0 \mathrm{~mol}$ $\mathrm{Kg}^{-1}$ in each phase in the later case.

The enthalpic and entropic changes imply respectively, the energetic requirements and the molecular randomness (increase or decrease in the molecular disorder), implied in the net transfer of the drug from water to different organic media. In general terms, it should be considered independently the behavior presented in each phase, before and after the partitioning process.

Since initially the solute is present only in water, then, it is necessary to create a cavity in the organic medium in order to accommodate the solute after transfer. This is an endothermic process, since an energy supply is necessary to separate the organic solvent molecules. When the solute molecules are accommodated in the organic phase an amount of energy is released due to solute-organic solvent interactions. This event implies an entropy increase in this medium due to mixing process.
On the other hand, after than a certain number of solute molecules have migrated from the aqueous to the organic phase, the original cavities occupied by the drug in the aqueous phase have been now occupied by water molecules. This event produces an energy releasing due to water-water interactions. However, depending on solute's molecular structure, it is also necessary to keep in mind the possible disruption of water structure, that is, the water molecules organized around the alkyl or aromatic groups of drug (hydrophobic hydration). This event in particular implies an intake of energy in addition to a local entropy increase by separation of some water molecules which originally were associated among them by hydrogen bonding (Tanford, 1973).

From Table IV it can be observed that for all cases, the transfer processes from water to organic media were endothermic, which imply high increments in the systems' net entropy. In principle, it could be said for the $\mathrm{CH} / \mathrm{W}$ system, that the high values in enthalpy and entropy are due mainly to disruption of water-icebergs present around the hydrocarbon groups of this drug (two aromatic rings and one methyl group), and on the other hand, the creation of a cavity in the cyclohexane to accommodate the solute. Both events, as was already said, imply an energy intake and a disorder increase at molecular level.

In the case of $\mathrm{ROH} / \mathrm{W}$ system, the enthalpy of transfer is relatively low, while the entropy of transfer has a middle value. These values could be explained in terms of a possible organization in the water-saturated octanol due to the replacement of an octanol molecule by one of drug. This replacement would be present in some of centers 
conformed by two water molecules and four octanol molecules, inside the microheterogeneus structure of this water-saturated organic solvent (Sangster, 1997; Mora et al., 2005). The previous event releases energy and compensates the molecular disorder produced by the drugorganic solvent mixing process.

For the IPM/W and CLF/W systems, the enthalpies and entropies of transfer are relatively low compared with the other systems. Because, some information about the structural properties for these water-saturated organic solvents is not available at the moment, it is not possible to explain these results at molecular level.

On the other hand, in the case of liposomes, besides of that previously described for the aqueous media in the $\mathrm{CH} /$ W system (which may be also valid for the ROH/W, IPM/W and CLF systems), because of the highly organized structure of phospholipidic bilayers, the energy requirement for separate the bilayers, in order to accommodate the solute molecules, implies a relatively high enthalpy of transfer. The same event implies a high increment in the systems' entropy by the disorder generate inside the vesicle bilayers.

By comparing the values obtained for both thermodynamic properties, it follows that they are higher for DPPC liposomes (rigid state), than those for DMPC liposomes (fluid state). This result would be explained in terms of the lower flexibility of DPPC liposomes with respect to DMPC liposomes, and therefore, the higher energy requirements for accommodate the solute inside the DPPC bilayers. This behavior is similar to that presented by the liposome partitioning of any other drugs, such as benzocaine and some sulfonamides (Martínez, Gómez, 2002; Ávila, Martínez, 2003).

Equations (9) and (10) were used in order to evaluate the respective contributions in absolute values for enthalpy and entropy toward the standard Gibbs free energy of transfer and indeed to identify the dominant effect on transfer, that is, energy changes or molecular organization changes. Similar equations have been used recently in order to evaluate the relative contributions by enthalpy and entropy to the free energy of solvation of some nonsteroidal anti-inflammatory drugs studying the solution process in several solvents (Perlovich et al., 2003, 2004). The respective contributions for all the partitioning systems evaluated are also presented in table IV.

$$
\begin{gathered}
\% \zeta_{H}=100 \frac{\left|\Delta H_{w \rightarrow o}^{0 X}\right|}{\left|\Delta H_{w \rightarrow o}^{0 X}\right|+\left|T \Delta S_{w \rightarrow o}^{0 X}\right|} \\
\% \zeta_{T S}=100 \frac{\left|T \Delta S_{w \rightarrow o}^{0 X}\right|}{\left|\Delta H_{w \rightarrow o}^{0 X}\right|+\left|T \Delta S_{w \rightarrow o}^{0 X}\right|}
\end{gathered}
$$

Based on data for $\% \mathrm{z}_{H}$ and $\% \mathrm{z}_{T S}$ from table IV it follows that transfer of KTP from water to all organic systems is driven mainly by organizational changes. This confirms fully that previously observed for the signs of entropies of transfer, which are positive in all cases, that is, the partitioning is entropy driven because of enthalpies are also positive in all cases. Although in the case of IPM/W and CLF/W almost equivalent contributions of enthalpy and entropy toward the transfer process is supposed. The $\mathrm{ROH} / \mathrm{W}$ system has the higher entropy contribution toward transfer followed by liposomes. As has been already said, the dominant effect of entropy on Gibbs free energy of transfer from water to $\mathrm{ROH}$ would be due to disorder increase presented in the micro-heterogeneous structure of water-saturated octanol by the solute accommodation (Sangster, 1997; Mora et al., 2005).

\section{Thermodynamics of KTP solvation}

According to Katz and Diamond (1974), the values of thermodynamic functions of partitioning, $\Delta G_{w \rightarrow 0}^{0 X}$, $\Delta H_{w \rightarrow 0}^{O X}$ and $\Delta S_{w \rightarrow 0}^{O X}$, depend both upon interactions between drug and water and upon interactions between drug and organic medium. In order to obtain quantities that can be discussed solely in terms of drug-organic medium interactions, the contributions of drug-water must be removed. This can be accomplished by referring to hypothetic processes presented in Figure 5:

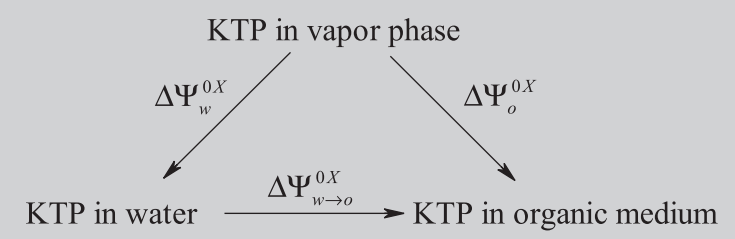

FIGURE 5 - Transfer processes of KTP between water, organic medium, and vapor phase.

In this scheme (Figure 5), $\Psi^{O X}$, stands for any thermodynamic function whose change can be measured when one mole of drug is transferred between water, organic medium and the vapor phase. The term $\Delta \Psi_{\mathrm{w}}^{O X}$ represents the standard Gibbs free energy, enthalpy, or entropy of solvation of drug in water, while the term $\Delta \Psi_{O}^{0 X}$ represents correspondingly the standard Gibbs free energy, enthalpy, or entropy of solvation of drug in organic medium. From this, the following equations can be stated:

$$
\Delta \Psi_{w \rightarrow o}^{0 X}=\Psi_{o}^{0 X}-\Psi_{w}^{0 X}
$$




$$
\begin{aligned}
& \Delta \Psi_{o}^{0 X}=\Psi_{o}^{0 X}-\Psi_{v}^{0 X} \\
& \Delta \Psi_{w}^{0 X}=\Psi_{w}^{0 X}-\Psi_{v}^{0 X}
\end{aligned}
$$

where, $\Psi_{v}^{O X}$ is the respective thermodynamic value of the function in the vapor phase. The $\Delta \Psi_{w \rightarrow o}^{O X}$ values for KTP obtained from partitioning experiments are presented in table IV. On the other hand, the $\Delta \Psi_{w}^{O X}$ values of solvation of this drug in water have been presented by Perlovich et al. (2003). From these values, the $\Delta \Psi_{o}^{O X}$ values were calculated by means of:

$$
\Delta \Psi_{o}^{0 X}=\Delta \Psi_{w \rightarrow o}^{0 X}+\Delta \Psi_{w}^{0 X}
$$

Table V shows the standard thermodynamic functions of solvation of KTP in water presented by Perlovich et al. (2003). The same table present also the standard thermodynamic functions of solvation of this drug in all organic phases studied, including the respective contributions by enthalpy and entropy toward solvation in each medium (calculated by means of expressions analogous to equations (9) and (10)). In all cases, the $\Delta G_{\text {solv }}^{0 X}$ and $\Delta H_{\text {solv }}^{0 X}$ values are negative. These results indicate the preference of KTP by organic media respect to its vapor phase, and also indicate that the solvation process is enthalpy driven. In the case of $\Delta S_{\text {solv }}^{0 X}$, this function is negative for organic solvents, which implies a diminishing in the molecular randomness by passing of drug molecules from vapor state to liquid media. On the other hand, for liposomes this function has positive values which indicate a net increase in disorder after drug-lecithins interactions which overlap the diminishing in molecular randomness by passing of drug molecules from vapor state to condensate state inside the liposomes. Nevertheless, the meaning of these positive values at molecular level is unclear. According to $\zeta_{H}$ and $\zeta_{T S}$ values, the enthalpy is the main property contributing to solvation process in all media, including the aqueous phase.

In order to clarify and understand the specific interactions presented between KTP and DMPC and DPPC liposomes it would be important to dispose information about UV, IR and NMR spectral data, and DSC calorimetry, among others. These instrumental techniques have been used in other studies about solubility and partition of other drugs in aqueous, organic, and liposomal systems. Some properties of pharmaceutical compounds studied have been the solubility of parabens in dioxane-water mixtures (Shihab et al., 1971), the interaction of propranolol with liposomes (Surewics, Leyko, 1981), the interaction of phenylbutazone in DMPC and DPPC liposomes (Sainz et al., 1993), and the interaction of paclitaxel with DPPC liposomes (Zhao et al., 2004), among several others.

\section{CONCLUSIONS}

From the previously exposed analysis, in general terms it could be concluded that KTP has mainly a lipophilic behavior although this drug is not certainly a hydrophobic drug. On the other hand, this drug possess a greater affinity by liposomes with respect to all evaluated organic solvents, which confirm the original idea about the greater discriminating power of liposomal vesicles in QSAR studies. Finally, it will be very important to analyze the surface behavior of this drug in other organic systems such as micelles, in order to evaluate if KTP is amphiphilic in nature, as it was demonstrated for ibuprofen.

TABLE V - Standard Gibbs free energy $\left(\Delta G_{\text {solv }}^{0}\right)$, enthalpy $\left(\Delta H_{\text {solv }}^{0}\right)$, and entropy for solvation $\left(\Delta S_{\text {solv }}^{0}\right)$ of KTP in water and

\begin{tabular}{|c|c|c|c|c|c|c|}
\hline System & $\begin{array}{c}\Delta G_{\text {solv }}^{\mathbf{0}} / \\
\mathbf{k J} \mathbf{m o l}^{-1}\end{array}$ & $\begin{array}{c}\Delta \boldsymbol{H}_{\text {solv }}^{\mathbf{0}} / \\
\mathbf{k J ~ m o l}^{-1}\end{array}$ & $\begin{array}{c}\Delta S_{\text {solv }}^{0} / \\
\mathbf{J ~ m o l}^{-1} \mathbf{K}^{-1}\end{array}$ & $\begin{array}{c}T \Delta S_{\text {solv }}^{0} / \\
\mathbf{k J ~ m o l}^{-1}\end{array}$ & $\zeta_{H}$ & $\zeta_{T S}$ \\
\hline $\mathrm{W}^{\text {(a) }}$ & -34.20 & -92.88 & -196.8 & -58.74 & 61.3 & 38.7 \\
\hline $\mathrm{CH}$ & -45.13 & -52.0 & -23 & -6.9 & 88.3 & 11.7 \\
\hline $\mathrm{ROH}$ & -56.17 & -87.94 & -107 & -31.8 & 73.4 & 26.6 \\
\hline IPM & -52.72 & -83.6 & -162.0 & -48.4 & 63.4 & 36.6 \\
\hline CLF & -53.29 & -85.1 & -167.6 & -50.0 & 63.0 & 37.0 \\
\hline DMPC & -68.55 & -46.6 & 74 & 21.9 & 68.1 & 31.9 \\
\hline DPPC & -66.92 & -36.7 & 101 & 30.1 & 54.9 & 45.1 \\
\hline
\end{tabular}
several organic systems. Relative contributions of enthalpy $\left(\zeta_{H}\right)$ and entropy $\left(\zeta_{T S}\right)$ toward solvation processes at 25.00 $\pm 0.05{ }^{\circ} \mathrm{C}$

(a) Reported by Perlovich et al. (2003). 


\section{ACKNOWLEDGEMENTS}

We thank the Banco de la República and DINAINUniversidad Nacional de Colombia (UNC) for financial support, and also GENFAR Colombia S.A. for providing the ketoprofen. In addition, we thank the Department of Pharmacy of UNC for facilitating the equipment and laboratory facilities.

\section{RESUMO}

\section{Termodinâmica da partição da solvatação do cetoprofeno em alguns sistemas solvente orgânico/ tampão e lipossomas}

A termodinâmica da partição de cetoprofeno (KTP) foi estudada em diferentes sistemas solvente/tampão, tais como ciclo-hexano $(\mathrm{CH} / W)$, octanol $(\mathrm{ROH} / W)$, miristato de isopropila $(I P M / W)$, clorofórmio (CLF/ $W$ ), assim como em lipossomas de dimiristoilfosfatidilcolina (DMPC) e de dipalmitoil-fosfatidilcolina (DPPC). Em todos os casos, os coeficientes racionais da partição $\left(K_{O / w}^{X}\right)$ foram maiores que a unidade, conseqüentemente as energias livres de transferência padrão foram negativas, o que indica afinidade elevada de KTP para meios orgânicos. Os valores $K_{O / w}^{X}$ foram aproximadamente 85 vezes maiores no sistema $\mathrm{ROH} / \mathrm{W}$ em relação ao sistema $\mathrm{CH} / W$, indicando-se, assim, alta contribuição da ligação hidrogênio sobre a partição. No entanto, para os sistemas IPM/W e CLF/W os valores $K_{O / w}^{X}$ foram somente três ou quatro vezes menores que aqueles observados em $\mathrm{ROH} / W$. De outra parte, os valores $K_{O / w}^{X}$ foram aproximadamente $75 \mathrm{ou}$ 150 vezes maiores nos lipossomas, comparados ao sistema $R O H / W$, segundo o caso, o que indica grau elevado de imobilização de KTP nas bicamadas elou contribuição eletrostática sobre a partição. Em todos os casos, as entalpias e as entropias padrão de transferência de KTP desde a água até os meios orgânicos foram positivas indicando algum grau de participação da hidratação hidrofóbica nos processos de partição. Finalmente, usando dados previamente relatados para o processo de solvatação de KTP na água, foram calculadas as funções termodinâmicas associadas com os processos de solvatação de KTP em todas as fases orgânicas avaliadas.

UNITERMOS: Cetoprofeno. Coeficiente de partição. Solventes orgânicos. Lipossomas. Termodinâmica de transferência.

\section{REFERENCES}

ABE, M.; OGINO, K.; YAMAUCHI, H. Solubilization of organic compounds by vesicles. In: CHRISTIAN, S.D.; SCAMEHORN, J.F. (Eds.). Solubilization in surfactant aggregates. New York: Marcel Dekker, 1995.p. 333-363.

AHMED, M.; BURTON, J.S.; HADGRAFT, J.; KELLAWAY, I.W. Thermodynamics of partitioning and efflux of phenothiazines from liposomes. J. Membrane Biol., New York, v. 58, n. 3, p. 181-189, 1981.

AHMED, A.M.S.; FARAH, F.H.; KELLAWAY, I.W. The thermodynamics of partitioning of phenothiazines between phosphate buffer and the lipid phases of cyclohexane, noctanol, and DMPC liposomes. Pharm. Res., New York, v. 2 , n. 3, p. 119-124, 1985.

ANDERSON, N.H.; DAVIS, S.S.; JAMES, M.; KOJIMA, I. Thermodynamics of distribution of p-substituted phenols between aqueous solutions and organic solvents and phospholipid vesicles. J. Pharm. Sci., Washington, v. 72, n. 4, p. 443-448, 1983.

AVILA, C.M.; MARTÍNEZ, F. Thermodynamics of partitioning of benzocaine in some organic solvent/buffer and liposome systems. Chem. Pharm. Bull., Tokyo, v. 51, n. 3, p. 237-240, 2003.

BAENA, Y.; PINZÓN, J.A.; BARBOSA, H.; MARTÍNEZ, F. Temperature dependence of the solubility of some acetanilide derivatives in several organic and aqueous solvents. Phys. Chem. Liquids, London, v. 42, n. 6, p. $603-$ 613, 2004a.

BAENA, Y.; PINZÓN, J.; BARBOSA, H.; MARTÍNEZ, F. Estudio termodinámico de la transferencia de acetaminofén desde el agua hasta el octanol. Rev. Bras. Cienc. Farm., Sao Paulo, v. 40, n. 3, p. 413-420, 2004b.

BAENA, Y.; PINZÓN, J.; BARBOSA, H.; MARTÍNEZ, F. Thermodynamic study of transfer of acetanilide and phenacetin from water to organic solvents. Acta Pharm., Zagreb, v. 55, n. 2, p. 195-205, 2005.

BANGHAM, A.D. Liposomes: the Babraham connection. Chem. Phys. Lipids, Dublin, v. 64, n. 1-3, p. 275-285, 1993.

BARKER, N.; HADGRAFT, J. Facilitated percutaneous absorption: a model system. Int. J. Pharm., Amsterdam, v. 8, p. 193-202, 1981. 
BETAGERI, G.V.; ROGERS, J.A. Thermodynamics of partitioning of b-blockers in the n-octanol-buffer and liposome systems. Int. J. Pharm., Amsterdam, v. 36, p. 165-173, 1987.

BETAGERI, G.V.; DIPALI, S.R. Partitioning and thermodynamics of dipyridamole in the n-octanol/buffer and liposome systems. J. Pharm. Pharmacol., London, v. 45, n. 10, p. $931-933,1993$.

BETAGERI, G.V.; NAYERNAMA, A.; HABIB, M.J. Thermodynamics of partitioning of nonsteroidal antiinflammatory drugs in the n-octanol/buffer and liposome systems. Int. J. Pharm. Adv., New York, v. 1, n. 3, p. 310319, 1996.

BEVINGTON, P.R. Data reduction and error analysis for the physical sciences. New York: McGraw-Hill, 1969. p. 5665.

CEVC, G. Lipid properties as a basis for membrane modeling and rational liposome design. In: GREGORIADIS, G. (Ed.). Liposomes technology. Boca Raton: CRC Press, 1993. v. 1, p. 21.

DAL POZZO, A.; DONZELLI, G.; LIGGERI, E.; RODRIGUEZ, L. Percutaneous absorption of nicotinic acid derivatives in vitro. J. Pharm. Sci., Washington, v. 80, n. 1, p. 54-57, 1991.

DALLOS, A.; LISZI, J. (Liquid + liquid) equilibria of (octan1-ol + water) at temperatures from $288.15 \mathrm{~K}$ to $323.15 \mathrm{~K}$. J. Chem. Thermodyn., Amsterdam, v. 27, n. 4, p. 447-448, 1995.

DIAMOND, J.M.; KATZ, Y. Interpretation of nonelectrolyte partition coefficients between dimyristoyl lecithin and water. J. Membr. Biol., New York, v. 17, n. 1, 121-154, 1974.

FINI, A.; DEMARIA, P.; GUARNIERI, A.; VAROLI, L. Acidity constants of sparingly water-soluble drugs from potentiometric determinations in aqueous dimethyl sulfoxide. J. Pharm. Sci., Washington, v. 76, n. 1, p. 48$52,1987$.

GO, M.L.; NGIAM, T.L.; ROGERS, J.A. Thermodynamics of the partitioning of 7-chloro-4-(4'-methoxy) anilinoquinolone and its cyclized analog in octanol-buffer and liposome systems. Chem. Pharm. Bull., Tokyo, v. 43, n. 2, p. 289-294, 1995.
GO, M.L.; NGIAM, T.L. Thermodynamics of partitioning of the antimalarial drug mefloquine in phospholipid bilayers and bulk solvents. Chem. Pharm. Bull., Tokyo, v. 45, n. 12, p. 2055-2060, 1997.

HANSON, G.R. Analgesic, antipyretic, and anti-inflammatory drugs. In: GENNARO, A.R. (Ed.). Remington: The science and practice of pharmacy. 20th ed. Philadelphia: Lippincott Williams \& Wilkins, 2000. p. 1456-1460.

JAISWAL, J.; PODURI, R.; PANCHAGNULA, R. Transdermal delivery of naloxone: ex vivo permeation studies. Int. J. Pharm., Amsterdam, v. 179, p. 129-134, 1999.

KATZ, Y.; DIAMOND, J.M. Thermodynamic constants for nonelectrolyte partition between dimyristoyl lecithin and water. J. Membrane Biol., New York, v. 17, n. 1, p. 101-120, 1974.

KOYNOVA, R.; CAFFREY, M. Phases and phase transictions of the phosphatidycholines. Biochim. Biophys. Acta,Amsterdam, v. 1376, n. 1, p. 91-145, 1998.

LEO, A.; HANSCH, C.; ELKINS, D. Partition coefficients and their uses. Chem. Rev., Washington, v. 71, n. 6, p. 525$616,1971$.

LOZANO, H.R.; MARTÍNEZ, F. Funciones termodinámicas relativas a la transferencia del ketoprofén desde el agua hasta algunos sistemas orgánicos. Quím. Nova, São Paulo, v. 29, n. 4, p. 704-709, 2006.

MARTIN, A.; BUSTAMANTE, P.; CHUN, A.H.C. Physical pharmacy: physical chemical principles in the pharmaceutical sciences. 4. ed. Philadelphia: Lea \& Febiger, 1993. p. 160-163.

MARTÍNEZ, F.; GÓMEZ, A. Thermodynamics of partitioning of some sulfonamides in 1-octanol/buffer and liposome systems. J. Phys. Org. Chem., New York, v. 15, n. 12 , p. $874-880,2002$.

MORA, C.P.; LOZANO, H.R.; MARTINEZ, F. Aspectos termodinámicos de la miscibilidad parcial entre el noctanol y el agua. Rev. Bras. Ciênc. Farm., Sao Paulo, v. 41, n. 1, p. 13-26, 2005.

PERLOVICH, G.L.; KURKOV, S.V.; KINCHIN, A.N.; BAUER-BRANDL, A. Thermodynamics of solutions IV: Solvation of ketoprofen in comparison with other NSAIDs. J. Pharm. Sci., Washington, v. 92, n. 12, p. 2502-2511, 2003. 
PERLOVICH, G.L.; KURKOV, S.V.; KINCHIN, A.N.; BAUER-BRANDL, A. Thermodynamics of solutions III: Comparison of the solvation of (+)-naproxen with other NSAIDs. Eur. J. Pharm. Biopharm., Amsterdam, v. 57, n. 2, p. 411-420, 2004.

ROGERS, J.A.; DAVIS, S.S. Functional groups contributions to the partitioning of phenols between liposomes and water. Biochim. Biophys. Acta, Amsterdam, v. 598, n. 2, p. 392-404, 1980.

SAINZ, M.C.; CHANTRES, J.R.; ELORZA, B.; ELORZA, M.A. DSC study of the action of phenylbutazone on DMPC and DPPC bilayers. Int. J. Pharm., Amsterdam, v. 89, 183-190, 1993.

SANGSTER, J. Octanol-water partition coefficients: fundamentals and physical chemistry. Chichester: John Wiley \& Sons, 1997. p. 1-55.

SEILER, P. Interconversion of lipophilicities from hydrocarbon/water systems into the octanol/water system. Eur. J. Med. Chem. -Chim. Therap., Amsterdam, v. 9, n. 5, p. 473-479, 1974.

SHIHAB, F.; SPROWLS, J.; NEMATOLLAHI, J. Solubility of alkyl benzoates III: Hydrogen bonding and solubility: a theoretical approach. J. Pharm. Sci., Washington, v. 60, n. 4, p. 622-623, 1971.
STEPHENSON, B.C.; RANGEL-YAGUI, C.O.; JUNIOR, A.P.; TAVARES, L.C.; BEERS, K.; BLANKSCHTEIN, D. Experimental and theoretical investigation of the micellarassisted solubilization of ibuprofen in aqueous media. Langmuir, Washington, v. 22, n. 4, p. 1514-1525, 2006.

SUREWICZ, W.K.; LEYKO, W. Interaction of propranolol with model phospholipid membranes: monolayer, spin label and fluorescence spectroscopy studies. Biochim. Biophys. Acta,Amsterdam, v. 643, n. 2, p. 387-397, 1981.

TANFORD, C. The hydrophobic effect: formation of micelles and biological membranes. New York: John Wiley, 1973. p. $1-200$

UNITED States Pharmacopeia. 28. ed. Rockville: United States Pharmacopeial Convention, 2004. p.1099-1100.

ZHAO, L.; FENG, S.S.; GO, M.L. Investigation of molecular interactions between paclitaxel and DPPC by Langmuir film balance and differential scanning calorimetry. $J$. Pharm. Sci., Washington, v. 93, n. 1, p. 86-98, 2004.

Recebido para publicação em 11 de julho de 2006 Aceito para publicação em 24 de novembro de 2006 